\title{
Exploring the Technological Pedagogical and Content Knowledge (TPACK) of Vocational High School's Accounting Teachers
}

\author{
Saringatun Mudrikah ${ }^{1}$, Jarot Tri Bowo Santoso ${ }^{2}$, Dwi Puji Astuti ${ }^{3}$ \\ \{saringatunmudrikah@mail.unnes.ac.id ${ }^{1}$ \} \\ Universitas Negeri Semarang, Indonesia ${ }^{1,2,3}$
}

\begin{abstract}
This study aims to discover the level mastery of Technological Pedagogical and Content Knowledge (TPACK) of vocational high schools in Kebumen and to find out the difference in the TPACK mastery level of accounting teachers based on gender, education level, and teaching experience. The research method used is the descriptive method with a quantitative approach. The population in this study is all accounting teachers as many as 65 people, and the instrument used was questionnaire. The results show that all TPACK of the Accounting teachers are in a good category; there is no difference in the mastery of TPACK between male and female teachers. In addition, there is a difference in TPACK mastery from teachers' level of education except in PK and PCK. Based on teaching experience, there is a significant difference in TK, TCK, and TPK. From the results of this study, it can be concluded that the Accounting teachers of vocational high schools in Kebumen have a good category level of mastery of TPACK that has been implemented in the learning process. Besides, there is no difference in the mastery of TPACK from gender, and there are differences in terms of education level and teaching experience.
\end{abstract}

Keywords: Accounting Teachers, Gender of teachers, Level of education, Teaching experience, TPACK, Vocational High School

\section{Introduction}

Quality Education is one of the goals formulated in the Sustainable Development Goals (SDGs) or sustainable development agreed upon by the UN forum, because quality education can determine the development of country. Developed countries are countries whose educational systems are capable of producing human resources that can compete in disruptive era. One of factors that influences the quality of education is teacher. Teacher is an important factor in the learning process because teacher is at the forefront in the process of implementing education. The skills possessed by a teacher become an important factor determining the quality of learning which will later affect the quality of students learning outcomes.

According to Constitution Number 14 of 2005 concerning Teachers and Lecturers it has been mentioned that the competencies that must be possessed by a teacher include: pedagogical competencies, professional competencies, social competencies, and personality competencies. Teachers are required to master the combined competence between content knowledge and pedagogical knowledge into new knowledge called Pedagogical Content Knowledge. PCK is a term to refer to the teacher's unique knowledge about how to teach content by considering the characteristics and conditions of students. 
The outbreak of the covid-19 pandemic has changed the learning system that used to be done face-to-face into online learning. For teacher, mastery of technology is a very important requirement in order to continue being able to carry out learning. Therefore, knowledge about technology is one of the competencies that must be possessed by teacher, not only competence in Pedagogical Content Knowledge (PCK) alone. Additional technological knowledge to supplement pedagogical knowledge and content knowledge (PCK) is needed because technological development requires the world of education to use technology in learning activities. This additional aspect of technology is known as the Technological Pedagogical and Content Knowledge (TPACK).

Accounting teacher is a subject that must always keep abreast of development and improve his/her knowledge given the rapid development of accounting. The inclusion of village government accounting subject becomes one of the new subjects where this subject had never existed in previous curricula. Accounting teacher must know and be able to understand well about the latest accounting standard that applies in Indonesia. An accounting teacher must also be aware of the challenge of the accounting profession, understand the blueprint to be faced as an accountant, understand the theory and practice of applying Village Government Accounting Standard so that later teacher can teach the students properly and correctly, and all of these are closely related to Technological Pedagogical and Content Knowledge (TPACK).

TPACK is a new type of knowledge that teacher must master to be able to integrate technology well in learning. TPACK is originally developed by Shulman's [1] who described Pedagogical and Content Knowledge (PCK), then to describe how teacher's understanding of learning technology is linked to PCK and with others to produce effective learning using technology. TPACK is formed on a combination of 3 basic types of knowledge, namely Technological Knowledge, Pedagogical Knowledge, Content Knowledge. The result of the integration of 3 basic knowledge, produces 4 new knowledge, including Pedagogical Content Knowledge, Technological Content Knowledge, Technological Pedagogical Knowledge and Technological Pedagogical Content Knowledge. The following is an overview of the TPACK framework:

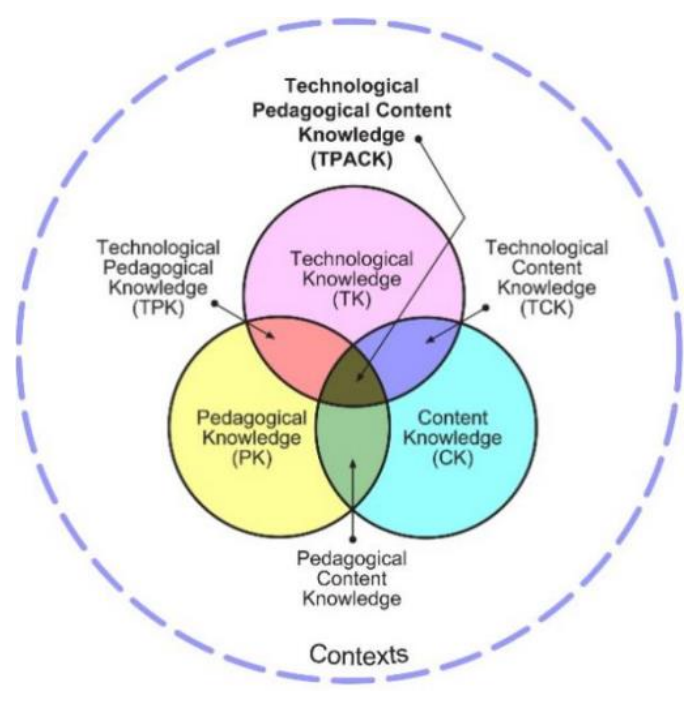

Fig. 1. TPACK Framework [2]. 
Figure 1, clearly shows the interrelation between 3 basic knowledge which results in 4 knowledge. The interaction of the three main components of knowledge, namely PK, CK, and TK requires the teacher to have an intuitive understanding of it, the way is to deliver the material using appropriate teaching method and technology. The TPACK framework forms a Venn diagram with three overlapping levels [2].

Research on TPACK has been carried out, both on teacher and prospective teacher. The TPACK framework has provided a means for researcher and practitioner of educational technology to examine teacher's TPACK. Baran, Chuang and Thompson [3] states that in addition to knowing the knowledge of teachers and prospective teachers, TPACK can provide clarity on specific intervention in research and development project and thus can improve the ability to design and test good technological approach in learning. The TPACK framework has offered several possibilities for conducting research in teacher's education, teacher's professional development, and teacher's use of technology. In addition, it has enabled teacher, researcher, and lecturer to build interactions between technology, content, and pedagogy while they are in class [2]. The TPACK framework developed by Koehler et al. [2] includes 7 important components:

Pedagogical Knowledge (PK). PK is teacher's in-depth knowledge about learning strategy. General knowledge about pedagogy includes understanding how students learn, class management skill, learning plan, and student's assessment. Chai, Koh and Tsai [4] explains that PK is knowledge about student learning, teaching method, different theory of education, and assessment of learning to teach material to a subject matter. Koehler et al. [2] reveals that PK is a set of skills that teacher must develop to manage and organize teaching and learning activities for desired learning outcomes.

Content Knowledge (CK). CK refers to the knowledge or special nature of a discipline or subject matter. Shulman [1] explains CK is knowledge of the actual subject matter that must be learned or taught to students, including knowledge of the main facts, concepts, theories, and procedures in a given subject, knowledge of the explanation of the framework that organizes and connects ideas, and knowledge of the rule of finding clue and evidence.

Technological Knowledge (TK). TK used in the TPACK framework is associated with understanding of Information and Communication Technology. TK is defined as teacher knowledge about the latest technology used in the educational environment. Chai, Koh and Tsai [4], Can, Erokten and Bahtiyar [5] mentions that TK is knowledge about how to use hardware and software of ITC.

Pedagogical Content Knowledge (PCK). The PCK framework developed begins with the belief that teaching is not only about transferring knowledge to students but also about how to teach good content until students understand. PCK is knowledge about representing content knowledge and adopting pedagogical strategy to make specific content or topic easier for students to understand [1][6].

Technological Content Knowledge (TCK). Chai et al. [6] defines TCK as knowledge about how to use technology to convey learning material differently. TCK refers to knowledge of how technology can create new representation for certain content. Teacher who has knowledge of technology and content understand that by using certain technology, they can change the way of students learn to understand the content of lesson. The technology in question is ICT whose use can support accounting learning in vocational high school.

Technological Pedagogical Knowledge (TPK). TPK refers to knowledge of how various technologies can be used in learning and understanding that using technology can change the way of teacher teaches. TPK is the teacher's understanding of how the learning process can change when technology is used in certain way [2][7]. This knowledge enables teacher to 
understand what technology can be used in achieving learning objective, and to understand the selection of tool that is most appropriate in the pedagogical approach.

Technological Pedagogical Content Knowledge (TPACK). TPACK is understanding of how technology can be used creatively to meet pedagogical need in delivering certain content [2]. TPACK refers to the knowledge needed by teacher to integrate technology into learning according to the discipline that teacher teaches. The teacher must have this knowledge in order to understand intuitively about the complex interaction between the three basic components of knowledge $(\mathrm{CK}, \mathrm{PK}, \mathrm{TK})$ by teaching content using appropriate pedagogical method and technology.

Research using the TPACK framework has been conducted to measure the use of ICT in various learning [6][8]. Research on understanding TPACK is also related to gender, level of education, and teaching experience [9][10][11][12][13] where these three factors affect several components of TPACK. This research focuses on the analysis of TPACK mastery of accounting teachers of vocational high schools in Kebumen Regency and the factors that influence it from gender, education level, and teaching experience.

\section{Research Methods}

This research is a descriptive study with a quantitative approach. Descriptive research is a type of research used to describe facts and phenomena related to conditions that occur in the field. This study describes the mastery of accounting teacher's TPACK. While the quantitative approach is used to obtain the significance of the relationship between the variables studied, namely the relationship between TPACK mastery with gender, education level, and teaching experience.

The population in this study were all accounting teachers of vocational high schools who are subject teachers conference of accounting in Kebumen Regency, Central Java, Indonesia consisting of 65 people. The sampling technique used is the saturation sampling technique. The instrument used to collect research data is questionnaire. The data obtained are analyzed descriptively and inferentially. Inferential analysis with the Independent Sample t-test was used to determine the TPACK mastery level of accounting teachers by gender, education level, and teaching experience.

\section{Result and Discussion}

The results of the descriptive analysis of the TPACK mastery of Accounting teachers at vocational high schools in Kebumen is explained in detail in the following table:

Table 1. Descriptive Data on the Level of TPACK Mastery of Accounting Teachers

\begin{tabular}{cccccc}
\hline Component & Min & Max & Mean & Std. Dev & Category \\
\hline TK & 1 & 5 & 3,56 & 0,75 & Good \\
CK & 2 & 5 & 3,25 & 0,65 & Good \\
PK & 1 & 5 & 3,71 & 0,59 & Good \\
PCK & 2 & 5 & 3,71 & 0,57 & Good \\
TCK & 1 & 5 & 3,54 & 0,71 & Good \\
TPK & 2 & 5 & 3,58 & 0,73 & Good \\
\hline
\end{tabular}




\begin{tabular}{cccccc}
\hline TPCK & 1 & 5 & 3,43 & 0,71 & Good \\
\hline \multicolumn{4}{c}{ Source: Data processed in 2020. }
\end{tabular}

Based on table 1, it can be seen that the level of TPACK mastery of Accounting teachers at vocational high schools in Kebumen as a whole which includes 7 components are all included in good category. In TK, PK, TCK, and TPCK components, the minimum score is 1 and the maximum score is 5. While for CK, PCK, and TPK components, the minimum score is 2 and the maximum score is 5. The average score of each component with the highest score is found in PK and PCK components with each score of 3,71 with standard deviation of 0,59 and 0,57 while the lowest average values are found in CK component with value of 3,25 and standard deviation of 0,65 .

PK is the teacher's special knowledge in creating and facilitating effective teaching and learning environment for all students, regardless of subject matter, while PCK relates to content knowledge related to the teaching process. PCK is different from various types of content, because PCK is combination of content and pedagogy with the aim of developing better teaching practice for content.

Scores on the PK component obtain higher mean results when compare with other components which means that mastery related to the use of learning strategy carried out by accounting teachers of vocational high schools in Kebumen is appropriate. In addition, in the learning process the teacher also helps students and monitors learning independently. The teacher also helps students reflect on the learning strategy that has been applied to the learning process, has planned structured group activities for students, and is accustomed to guiding students during the group learning process.

In addition to the high PK score, the same score is also obtained on the PCK component. The acquisition of mean score of high enough PCK components can be interpreted that without the use of technology by accounting teachers of vocational high schools in Kebumen can still overcome common misconception that is sometimes experienced by students and teacher can choose effective teaching approach to guide students to think and learn from subject matter that is delivered.

The lowest mean score is in the CK component. This component is related to knowledge about scientific material taught by the teacher to students. The scientific material referred to in this case is related to accounting material in vocational high schools. The acquisition of this low CK score is due to many accounting teachers of vocational high schools in Kebumen who have not used the latest sources such as new textbook, the use of journal in supporting learning, and to the scientific treasure not yet widely practiced by teachers. In addition, some of these teachers also rarely take part in activities or seminars related to the fields of accounting.

Other TPACK components are almost the same for the mean score obtained, namely TK $(3,56)$, TCK $(3,54)$, TPK $(3,58)$, and TPCK $(3,43)$ and the four components are included in good category. The TK component relates to teacher knowledge about the latest technology used by teacher in supporting the learning process [2][14]. The average accounting teachers of vocational high schools in Kebumen can be said to have a good understanding of technology and have been able to use it in accounting learning in the classroom.

The TCK component deals with how to use technology to convey learning material differently [2]. Submission of material differently means conveying material creatively so that the learning process is fun for students [14]. So, it can be interpreted that the average accounting teachers of vocational high schools in Kebumen have mastered TCK $(3,54)$ and are included in good category. 
In addition, result of 3,58 is obtained for TPK component. This component refers to knowledge of how various technologies can be used in learning and understanding that using technology can change the way of teacher teaches. Mastery of TPK makes the understanding of accounting teachers about how the learning process can change when technology is used in certain way [2][14].

The last component is TPCK with mean score 3,43. This component is related to how technology can be used creatively to meet pedagogical need in delivering certain content [2][14]. It can be interpreted that the mastery of TPCK in accounting teachers of vocational high schools in Kebumen is in good category, such as the ability to integrate accounting knowledge, pedagogic knowledge, and technological knowledge possessed to realize effective learning.

The difference in the mean level of TPACK mastery of Accounting teachers at vocational high schools in Kebumen is also analyzed based on gender difference, difference in educational level, as well as difference in teaching experience. The statistical test used is the independent sample t-test using SPSS software 21 version. The following are the results of the independent sample t-test for the average TPACK mastery results of Accounting teachers based on gender:

Table 2. Level of TPACK mastery of Accounting Teachers Based on Gender

\begin{tabular}{cccccc}
\hline \multirow{2}{*}{ Component } & \multicolumn{2}{c}{ Male } & \multicolumn{2}{c}{ Female } & \multirow{2}{*}{ Significance } \\
\cline { 2 - 4 } & Score & Std. Dev & Score & Std. Dev & \\
\hline TK & 38,64 & 6,345 & 34,93 & 5,723 & 0,059 \\
CK & 18,27 & 3,069 & 17,46 & 2,090 & 0,286 \\
PK & 22,55 & 3,857 & 22,20 & 2,483 & 0,708 \\
PCK & 15,36 & 1,859 & 14,80 & 1,897 & 0,368 \\
TCK & 11,64 & 1,206 & 10,41 & 1,786 & 0,073 \\
TPK & 11,55 & 2,162 & 10,56 & 1,829 & 0,118 \\
TPCK & 14,82 & 2,676 & 13,52 & 2,393 & 0,181 \\
\hline
\end{tabular}

Source: Data processed in 2020.

In table 2, all TPACK components for male teachers receives higher average scores compared to female teachers but with not too large difference. The independent sample t-test results show that all components of TPACK include TK, CK, PK, PCK, TCK, TPK, TPCK, value sig. $>0.05$ for all components. These results indicate that there is no difference in the mastery of TPACK between male and female teachers. Therefore, it can be concluded that based on the gender of TPACK mastery of accounting teachers at vocational high schools in Kebumen that there is no difference. This is consistent with the results of research conducted by Koh and Sing [13], Restiana and Pujiastuti [11], Jang and Tsai [9], Ozudogru and Ozudogru [8] which stated no significant difference based on gender found in the seven components TPACK.

The difference in the TPACK mastery of accounting teachers in addition to being differentiated by gender, is further differentiated based on the level of education. The level of education is divided into two categories, namely teacher with postgraduate degree qualification and teacher with undergraduate education qualification. The following is the table of TPACK mastery level based on education level:

Table 3. The level of TPACK Accounting Teachers based on Education Level

\begin{tabular}{cccccc}
\hline \multirow{2}{*}{ Component } & \multicolumn{2}{c}{ Undergraduate } & \multicolumn{2}{c}{ Postgraduate } & \multirow{2}{*}{ Significance } \\
\cline { 2 - 4 } & Score & Std. Dev & Score & Std. Dev & \\
\hline TK & 35,03 & 5,690 & 40,67 & 6,532 & 0,026 \\
CK & 17,42 & 2,261 & 19,33 & 1,751 & 0,049
\end{tabular}




\begin{tabular}{cccccc} 
PK & 22,20 & 2,683 & 22,83 & 3,371 & 0,594 \\
PCK & 14,78 & 1,912 & 16,00 & 1,265 & 0,133 \\
TCK & 10,47 & 1,726 & 12,00 & 1,549 & 0,015 \\
TPK & 10,54 & 1,841 & 12,50 & 1,761 & 0,015 \\
TPCK & 13,59 & 2,393 & 15,17 & 2,994 & 0,020 \\
\hline \multicolumn{5}{c}{ Source: Data processed in 2020. }
\end{tabular}

In table 3, it is known that the average score of teachers with qualification of postgraduate obtains higher scores when compared to undergraduate in all TPACK components. While the results of the independent sample t-test show that the two TPACK components in the form of PK and PCK obtain significance values of 0,594 and 0,133. Both have sig values $>0.05$ which means there is no difference in the two groups over the mastery of the PK and PCK components of accounting teachers at vocational high schools in Kebumen Regency. It can be concluded that teachers with undergraduate and postgraduate level have the same pedagogic mastery and pedagogical content. Teachers with undergraduate and postgraduate level education are equally able to apply accounting learning method, technique, strategy and are able to develop lesson plan well. This is because the knowledge of learning planning has been obtained at the undergraduate level of education, so that both undergraduate and postgraduate teachers have mastered knowledge related to PK and PCK.

The results of the independent t-test of other TPACK components in the form of TK, CK, TCK, TPK, and TPCK show the value sig. $<0,5$. These results indicate there is difference between the two groups on the TPACK mastery of accounting teachers at vocational high schools in Kebumen. The difference in mastery of the components of TK, CK, TCK, TPK, and TPCK is strengthened [10][15].

Aside from being based on gender and teacher education levels, TPACK mastery is also tested based on teacher teaching experience. Teaching experience can be divided into two categories, namely $<10$ years teaching experience and $>10$ years teaching experience. The following is the TPACK mastery table based on teaching experience:

Table 4. The level of TPACK mastery of Accounting Teachers based on teaching experience

\begin{tabular}{cccccc}
\hline \multirow{2}{*}{ Component } & \multicolumn{1}{c}{$<$ Years' Experience } & \multicolumn{2}{c}{$>10$ Years' Experience } & \multirow{2}{*}{ Significance } \\
\cline { 2 - 4 } & Score & Std. Dev & Score & Std. Dev & \\
\hline TK & 38,48 & 4,100 & 33,95 & 6,227 & 0,003 \\
CK & 17,48 & 2,059 & 17,83 & 2,402 & 0,558 \\
PK & 22,26 & 2,598 & 22,26 & 2,829 & 0,999 \\
PCK & 10,14 & 1,678 & 14,71 & 1,991 & 0,308 \\
TCK & 11,09 & 1,676 & 15,22 & 1,802 & 0,043 \\
TPK & 10,33 & 1,647 & 11,43 & 1,946 & 0,025 \\
TPCK & 13,33 & 2,173 & 14,22 & 2,534 & 0,163 \\
\hline
\end{tabular}

Source: Data processed in 2020.

Based on teaching experience in Table 4, the mean CK, PCK, TCK, TPK, and TPCK scores are higher for teachers who have $>10$ years of teaching experience. While the PK component obtains the same score between teachers who have $<10$ years and $>10$ years teaching experience. TK component has different results because teachers with $<10$ years of teaching experience get higher scores than teachers who have $>10$ years of teaching experience.

While the results of the independent sample t-test show that TPACK components in the form of CK, PK, PCK, and TPACK obtain sig. > 0,05. These results indicate that there is no 
difference in the mastery of TPACK in the CK, PK, PCK, and TPCK components of accounting teachers at vocational high schools in Kebumen.

The results of the independent test t-test of other TPACK components in the form of TK, TCK, and TPK show value sig. $<0,05$. These results indicate that there is difference in the TPACK mastery of accounting teachers at vocational high schools in Kebumen based on their teaching experience. The difference in the components of TK, TCK, and TPK is because teachers with teaching experience $<10$ years are young teachers whose age is $<35$ years. This age is included in the category of millennial who are accustomed to using technology and have high technological literacy. In addition to mastering technology, groups of teachers with $<10$ years of teaching experience have the ability to develop student activities and tasks by involving the use of technology, being able to use computer applications in accounting learning (such as the use of MYOB Accounting software, Accurate software, and the application of the Village Financial System (Siskeudes) as well as skillfully using internet facilities to communicate with students. This is in accordance with the results of research conducted by Lin et al. [10], Jang and Tsai [9], Ozudogru and Ozudogru [8], Jang and Tsai [16], Eliyanto and Wibowo [17] which stated that teaching experience affects teacher competency and TPACK mastery.

\section{Conclusions}

The results of this research state that the level of TPACK mastery of accounting teachers at vocational high schools in Kebumen all its components are included in good category. Based on the independent sample t-test, there is no difference in the mastery of TPACK between male and female teachers. From the teacher education level, based on the results of the independent sample t-test, the components of TK, CK, TCK, TPK, and TPCK have value sig $<0.05$, which means that there is a difference in the two groups between undergraduate and postgraduate towards TPACK mastery. While based on teaching experience, the results of the independent sample t-test show that the components of TK, TCK, and TPK have value sig <0.05, which means that both groups between teachers who have teaching experience $<10$ years and teachers who have teaching experience $>10$ years there is a difference in TPACK mastery of accounting teachers at vocational high schools in Kebumen. What can be recommended for future researchers related to this research is to add other factors such as age, certification status, or other factors that can measure more deeply related to teacher's TPACK.

\section{References}

[1] L. S. Shulman, "Those Who Understand: Knowledge Growth in Teaching," Educ. Res. Rev., vol. 15, no. 2, pp. 4-14, 1986.

[2] M. J. Koehler, P. Mishra, and W. Cain, "What is Technological Pedagogical Content Knowledge (TPACK)?," J. Educ., vol. 193, no. 3, pp. 13-19, 2013.

[3] E. Baran, H. H. Chuang, and A. Thompson, "Tpack: An emerging research and development tool for teacher educators," Turkish Online J. Educ. Technol., vol. 10, no. 4, pp. 370-377., 2011.

[4] C. S. Chai, J. H. L. Koh, and C. C. Tsai, "Facilitating preservice teachers' development of technological, pedagogical, and content knowledge (TPACK)," Educ. Technol. Soc., vol. 13, no. 4, pp. 63-73.

[5] B. Can, S. Erokten, and A. Bahtiyar, "An Investigation of Pre-Service Science Teachers' Technological Pedagogical Content Knowledge,” Eur. J. Educ. Res., vol. 6, no. 1, pp. 51-57, 2017. 
[6] C. S. Chai, J. H. Ling Koh, C. C. Tsai, and L. W. Tan, "Modeling primary school pre-service teachers' Technological Pedagogical Content Knowledge (TPACK) for meaningful learning with information and communication technology (ICT)," Comput. Educ., vol. 57, no. 1, pp. 1184 1193, 2011.

[7] M. J. Koehler and P. Mishra, "Technological Pedagogical Content Knowledge: A Framework for Teacher Knowledge PUNYA MISHRA,” Teach. Coll. Rec., vol. 108, no. 6, pp. 1017-1054, 2006.

[8] M. Ozudogru and F. Ozudogru, "Technological pedagogical content knowledge of mathematics teachers and the effect of demographic variables," Contemp. Educ. Technol., vol. 10, no. 1, pp. $1-24,2019$.

[9] S. J. Jang and M. F. Tsai, "Exploring the TPACK of Taiwanese elementary mathematics and science teachers with respect to use of interactive whiteboards," Comput. Educ., vol. 59, no. 2, pp. 327-338, 2012.

[10] T. C. Lin, C. C. Tsai, C. S. Chai, and M. H. Lee, "Identifying Science Teachers' Perceptions of Technological Pedagogical and Content Knowledge (TPACK)," J. Sci. Educ. Technol., vol. 22, no. 3, pp. 325-336, 2013.

[11] N. Restiana and H. Pujiastuti, "Pengukuran Technological Pedagogical Content Knowledge untuk Guru Matematika SMA di Daerah Tertinggal," Mosharafa J. Pendidik. Mat., vol. 8, no. 1, pp. 83-94, 2019.

[12] N. Hidayati, P. Setyosari, and E. Soepriyanto, "Kompetensi Technological Pedagogical Content Knowledge (TPACK) Guru SOSHUM Setingkat SMA,” J. Kaji. Teknol. Pendidik., vol. 1, no. 4, pp. 291-298, 2019.

[13] J. H. L. Koh and C. C. Sing, "Modeling pre-service teachers' technological pedagogical content knowledge (TPACK) perceptions: The influence of demographic factors and TPACK constructs," ASCILITE 2011 - Australas. Soc. Comput. Learn. Tert. Educ., pp. 735-746, 2011.

[14] N. Janssen and A. W. Lazonder, Support for technology integration: Implications from and for the TPACK framework. Handbook of Technological Pedagogical Content Knowledge (TPACK) for Educators: Second Edition, 2016.

[15] C. Kuhn, A. C. Alonzo, and O. Zlatkin-Troitschanskaia, "Evaluating the pedagogical content knowledge of pre- and in-service teachers of business and economics to ensure quality of classroom practice in vocational education and training," Empir. Res. Vocat. Educ. Train., vol. 8, no. $1,2016$.

[16] S.-J. Jang and M.-F. Tsai, "Exploring the TPACK of Taiwanese secondary school science teachers using a new contextualized TPACK model," Australas. J. Educ. Technol., vol. 29, no. 4, pp. 566-580, 2013.

[17] E. Eliyanto and U. B. Wibowo, "Pengaruh Jenjang Pendidikan, Pelatihan, Dan Pengalaman Mengajar Terhadap Profesionalisme Guru Sma Muhammadiyah di Kabupaten Kebumen," J. Akuntabilitas Manaj. Pendidik., vol. 1, no. 1, pp. 34-47, 2013. 